\title{
AUTOMATIC CONTROL OF THE VESSEL'S MOVEMENT UNDER EXTERNAL CONDITIONS
}

\author{
Zinchenko S. M., Candidate of Technical Sciences, Senior Lecturer of Ship Management \\ Department, Kherson State Maritime Academy, e-mail: srz56@ukr.net, ORCID: 0000- \\ 0001-5012-5029; \\ Mamenko P. P., Deep Sea Captain, Senior Lecturer of Ship Management Department, \\ Kherson State Maritime Academy, e-mail: pavlo.mamenko@gmail.com; \\ Grosheva O. O., Senior Lecturer of Ship Management Department, Kherson State Maritime \\ Academy, e-mail: olgamelyaeva@gmail.com, ORCID: 0000-0001-9022-4697; \\ Mateychuk V. M., Head of Laboratory Navigation Simulator, Kherson State Maritime \\ Academy,e-mail: mateichykv@gmail.com
}

\begin{abstract}
The article deals with the issues of automatic control of the vessel's movement under external conditions of wind and current. A brief review of the sources was carried out and the limitations of the traditional control schemes with one stern rudder were shown. A control scheme with additional bow rudder has been proposed. It allows to reduce fuel consumption, the number of actuations of actuators and to increase reliability through redundancy management. A comparison of the proposed and traditional control schemes for mathematical modeling in the MATLAB environment has been made.
\end{abstract}

Keywords: control object, control system, mathematical model, numerical integration.

\section{DOI: 10.33815/2313-4763.2019.2.21.010-015}

Introduction. The effects of wind and current refer to external influences. Wind has an adverse effect on the movement and maneuvering of ships, especially those that have a greater freeboard and highly developed superstructures. The degree and nature of the impact of wind on the vessel depends on many factors, the main ones of which are: the area and location of the center of sail, the ratio of the size of the freeboard to the draft of the vessel, the force and direction of the wind relative to the diameter plane (DP) of the vessel, course and the speed of the vessel relative to the wind direction. The greatest influence on the ship has a wind directed perpendicularly or at an angle to the ship's DP. In this case, there is a drift (side drift), heeling, turn of the vessel to the wind or under the wind, as well as a change in the speed of movement. The flow directed at an angle to the vessel's DP also has an adverse effect. The presence of the lateral component of the flow leads to the appearance of the drift angle, a change in the speed of movement, lateral displacement and rotational movement of the vessel. Since almost all vessels operate under the conditions of external influences of wind and flow, the search for optimal schemes and optimal vessel control under external conditions allowing them to optimize their movement is an urgent scientific and technical task.

Currently, most transport ships use one or two engine, aft steering and thruster. At the same time, the thruster and engines are used for maneuvering only at low speeds, in maneuvering mode. At the transition, the engines used in the mode of ensuring the maximum speed of the vessel and are not used for maneuvering. Support a given course or driving along a given route is ensured only by the aft steering wheel. In autopilot mode, the PID regulator controls the aft steering wheel [1-3]. In work [1] an example of the Track Control System (Section 8) under conditions of wind exposure is shown, it is provided for keeping the vessel on the route. However, the presence of wind impact does not allow for a simultaneous zero drift angle, which leads to an increase in aerodynamic resistance, a decrease in speed, an increase in transition time and additional fuel consumption. In work [4] a system of automatic control of a ship with an additional bow rudder is described, it provides zero drift angle in the presence of external influences. According to the authors, this decision allows to reduce the overall resistance to movement of the vessel and fuel consumption. However, in the proposed system, the lateral deviation is calculated through the drift angle, which, in the presence of measurement and calculation errors, will lead to the accumulation of the lateral deviation error of the vessel from the trajectory and the need to organize a periodic return to the trajectory, which again is associated with additional fuel consumption. In work [5], 
the authors proposed a vessel control system with stern and bow rudders that kept the vessel on the route with a zero drift angle in the presence of external influences, which makes it possible to optimize the movement of the vessel in time and fuel consumption.

The purpose of this article is to check the efficiency of the proposed control scheme for a vessel with a stern and bow rudders, as well as a comparison of the effectiveness of the proposed scheme with a traditional control scheme with one stern rudder under external conditions.

Main part. Figure 1 shows the information management scheme with aft and bow rudders. The angular velocity of the vessel $\Omega_{z}$ from the angular velocity sensor 1 is served on the first input of the adder 9 , the angular deviation $\varphi-\varphi_{z}$ of the yaw angle from the track angle from the adder 5 is served to the second input of the adder 9 . On the third input of the adder 9 is served a signal $\int\left(\varphi-\varphi_{z)} d t\right.$ from the integrator 7 .

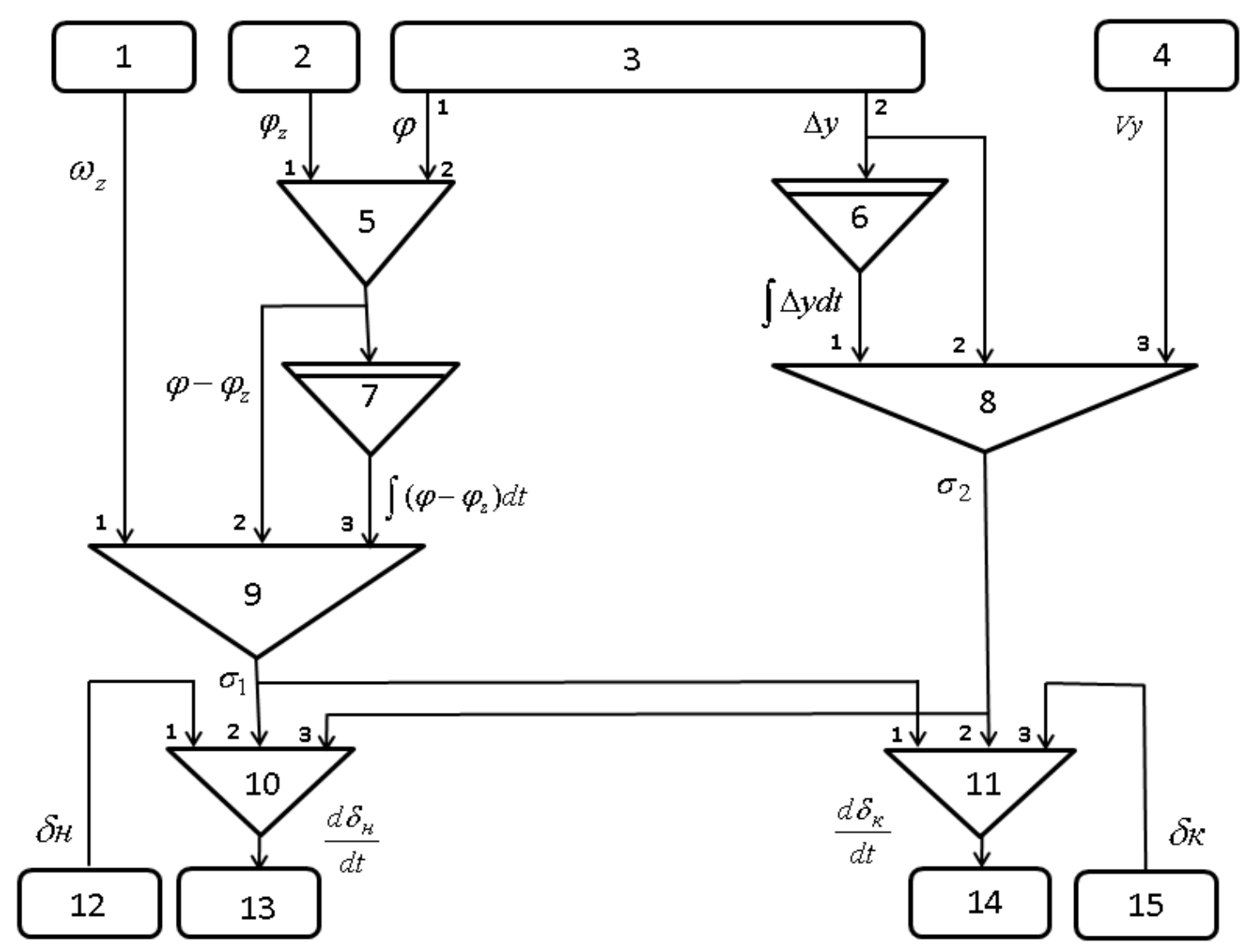

Figure 1 - Information management scheme with aft and bow rudders

Signal $\sigma_{1}=k_{\Omega} * \Omega_{z}+k_{\Delta \varphi} *\left(\varphi-\varphi_{z}\right)+k_{\int \Delta \varphi} * \int\left(\varphi-\varphi_{z}\right) d t$ is served from the output of the adder 9 to the second input of the adder 10 and to the first input of the adder 11, that ensures a steady reduce of the yaw angle to a predetermined value $\varphi=\varphi_{z}$ and $\beta=0$.

On the first input of the adder 8 is served the integral $\int \Delta y d t$ of the lateral deviation of the vessel relatively specified route from the integrator 6 , on the second input of the adder 8 and on the integrator 6 is served the lateral deviation $\Delta y$ of the vessel from the specified route from the second output of the satellite navigation system. To the third input of the adder 8 is served the lateral speed $V y$ of the vessel from the lateral speed sensor 4. Signal 
$\sigma_{2}=k_{v y} * V_{y}+k_{\Delta y} * \Delta y+k_{\int \Delta y} * \int \Delta y d t$ is served from the adder 8 to the second input of the adder 11 and to the third input of the adder 10, which reduces the deviation to zero $\Delta y=0$. If a signal $\sigma_{\kappa}=\sigma_{1}-\sigma_{2}$ is served to the stern-steering actuator 14 , and a signal $\sigma_{\mu}=-\sigma_{1}-\sigma_{2}$ to the baw-steering actuator 13, joint control of the stern and bow rudders will ensure reduce to $\beta=0$ and $\Delta y=0$, that is, the proposed control scheme with aft and bow rudders ensures the location of the vessel on a route with a zero drift angle.

The connection of the adder 10, the bow steering actuator 13 and the baw steering sensor 12 , shown in fig. 1 , provide filtering of the input signal $\sigma_{H}$.

The connection of the adder 11 , the aft steering actuator 14 and the aft steering sensor 15 , shown in fig. 1 , provide filtering of the input signal $\sigma_{\kappa}$.

$$
\begin{gathered}
T \frac{d \delta_{H}}{d t}=\sigma_{H}-\delta_{H}, T \frac{d \delta_{H}}{d t}+\delta_{H}=\sigma_{H}, \\
T \frac{d \delta_{\kappa}}{d t}=\sigma_{\kappa}-\delta_{\kappa}, T \frac{d \delta_{\kappa}}{d t}+\delta_{\kappa}=\sigma_{\kappa},
\end{gathered}
$$

where $\mathrm{T}$ is the constant time of the aperiodic link.

This filtering scheme is used to reduce the number of actuations of the aft and bow rudders. In addition, as can be seen from the information scheme, each of the rudders participates in the development of the angular and lateral deviations, which means that the proposed scheme has control redundancy.

Results of research. The effectiveness of the control system proposed in [3] was carried out by mathematical modeling in the MATLAB environment of the control object in a closed circuit with control systems [1] and [3] for different values of side wind. The simulation results are presented in fig. $2-3$.
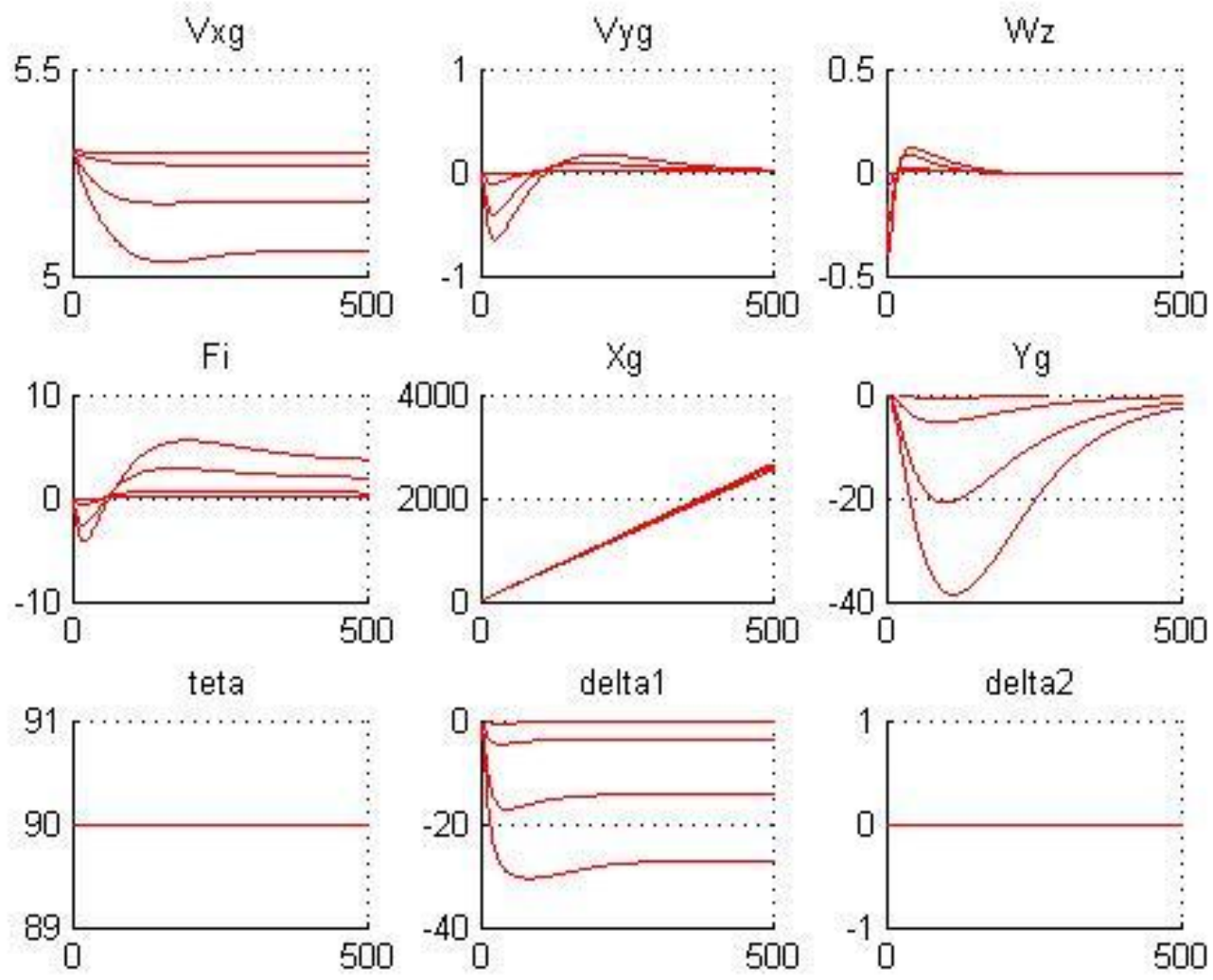
Figure 2 - Changing the parameters of the movement of the vessel when the stern rudder

Fig. 1 shows graphs of the time variation for the traditional control scheme: longitudinal velocity $\operatorname{Vxg}[\mathrm{m} / \mathrm{s}]$, the lateral velocity $\mathrm{Vyg}[\mathrm{m} / \mathrm{s}]$, the angular velocity $\mathrm{Wz}[\mathrm{deg} / \mathrm{s}]$, the course Fi [deg], the longitudinal displacement $\mathrm{Xg}[\mathrm{m}]$, the lateral displacement $\mathrm{Yg}[\mathrm{m}]$, the angle of deviation of the telegraph teta [deg] ] and the angle of deviation of the stern rudder delta1 [deg] for the values of side wind $\mathrm{Wyg}=1,2,3,3.5 \mathrm{~m} / \mathrm{s}$.

Fig. 2 shows the graphs of the time variation for the proposed control scheme: longitudinal velocity $\mathrm{Vxg}[\mathrm{m} / \mathrm{s}]$, the lateral velocity $\mathrm{Vyg}[\mathrm{m} / \mathrm{s}]$, the angular velocity $\mathrm{Wz}[\mathrm{deg} / \mathrm{s}]$, the course Fi [deg], the longitudinal displacement $\mathrm{Xg}[\mathrm{m}]$, the lateral offset $\mathrm{Yg}[\mathrm{m}]$, the angle of deviation of the telegraph teta [deg], the angle of deviation of the stern rudder delta1 [deg], the angle of deviation of the bow rudder delta2 [deg] for the values of side wind Wyg $=1,2,3,3.5,4.0,4.5$ $\mathrm{m} / \mathrm{s}$.
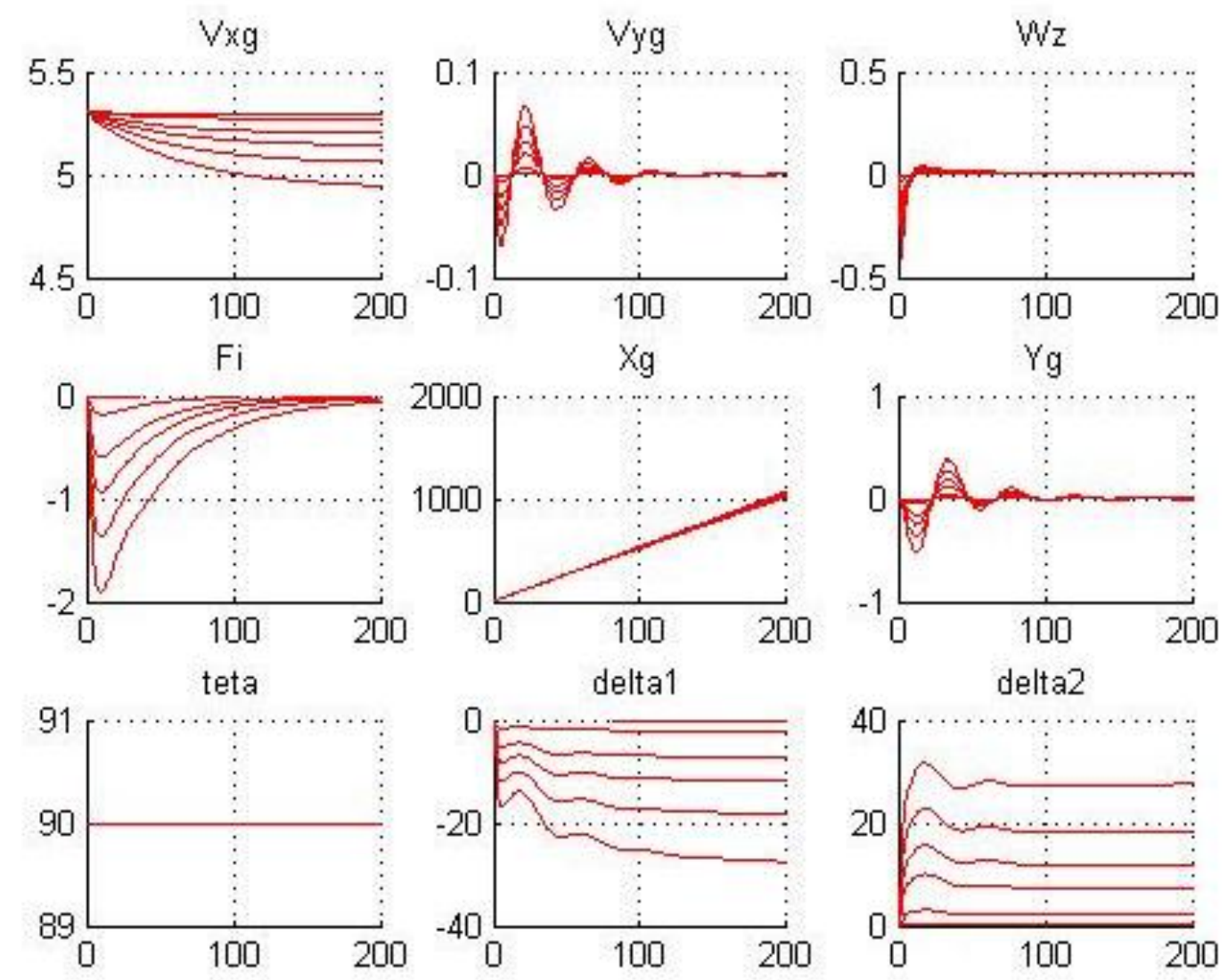

Figure 3 - Changing the parameters of the movement of the vessel in the management of the stern and bow rudders

Table 1 also shows the fuel consumption for the two control schemes: the control scheme using only the stern rudder and the control scheme using the stern and bow rudders for different values of the lateral wind speed Wyg. 
Table 1 - Fuel consumption $[\mathrm{kg}]$ per $5 \mathrm{~km}$ for two control schemes

\begin{tabular}{|c|c|c|}
\hline Control scheme & $\begin{array}{l}\text { Side wind speed } \\
\quad \mathrm{Wyg}[\mathrm{m} / \mathrm{s}]\end{array}$ & Fuel consumption $[\mathrm{kg}]$ per $5 \mathrm{~km}$ \\
\hline \multirow{5}{*}{$\begin{array}{l}\text { traditional control scheme } \\
\text { with only aft rudder }\end{array}$} & 1 & 63,89 \\
\hline & 2 & 64.227 \\
\hline & 3 & 65.310 \\
\hline & 3.5 & 66.826 \\
\hline & 4.0 & The system is not manageable \\
\hline \multirow{7}{*}{$\begin{array}{l}\text { proposed control scheme } \\
\text { with aft and bow rudders }\end{array}$} & 1 & 63.89 \\
\hline & 2 & 64.200 \\
\hline & 3 & 65.012 \\
\hline & 3.5 & 65.716 \\
\hline & 4 & 66.758 \\
\hline & 4.5 & 68.315 \\
\hline & 5.0 & The system is not manageable \\
\hline
\end{tabular}

Conclusions. From the above simulation results it can be seen that in the presence of external influences:

- transitional processes in the circuit with the stern and bow rudders flow several times faster than in the circuit with only one stern rudder;

- $\quad$ scheme with one stern rudder holds the vessel on the route, but does not provide a zero angle of drift;

- $\quad$ scheme with aft and bow rudders ensures that the vessel is held on a route with a zero drift angle;

- $\quad$ scheme with aft and bow rudders provides control for higher values of side wind than a circuit with only one aft rudder;

- $\quad$ scheme with aft and bow rudders is more economical compared with the scheme with only one aft rudder; the amount of fuel saved increases with increasing lateral component of the wind speed;

- the scheme with aft and bow rudders is more reliable due to redundancy of control channels.

\section{REFERENCES}

1. Vagushenko, L. L. \& Cimbal, N. N. Systemy avtomaticheskogo upravleniya dvigeniem sudna. Odessa : Feniks, 2007.

2. Sharlaj, G.N. Manevrirovanie I upravlenie morskim sudnom. Vladivostok, 2015.

3. Bikov, E. B., Kozlov, A. V. \& Turkin, I. I. Integrirovannye sistemy upravleniya dvijeniem sudna. Avtomatizaciya sudostroeniya. Retrieved from: http://www.remmag.ru/admin/upload_data/remmag/09-3/AMT.pdf

4. Klyachko, L. M., Ostretsov, G. E. \& Pamuhin, S. G. Apparatura avtomaticheskogo upravleniya dvigeniem sudna. Patent RF №2223197.

5. Zinchenko S.M., Grosheva O.O., Mateychuk V.M., Mamenko P.P., Pivovarov L.A. Systema vodinnya po marshrutu. Zayavka A201903052.

Зінченко С. М., Маменко П. П., Грошева О. О., Матейчук В. М. АВТОМАТИЧНЕ КЕРУВАННЯ РУХОМ СУДНА В УМОВАХ ЗОВНІШНІХ ВПЛИВІВ

Розглянуті питання автоматичного керування рухом судна в умовах зовнішніх впливів. Проведено короткий огляд джерел, показані недоліки традиійних схем керування з одним кормовим кермом при наявності зовнішніх впливів. Запропоновано схему керування з додатковим носовим кермом, яка дозволяє зменшити витрату палива, кількість спраџювань виконавчих пристроїв, а також збільшити надійність за рахунок резервування по управлінню. Проведено порівняння запропонованої і традиційної схем керування математичним моделюванням в середовищі MATLAB.

Ключові слова: об'єкт управління, система управління, математична модель, числове інтегрування. 
Зинченко С. Н., Маменко П. П., Грошева О. А., Матейчук В. Н. АВТОМАТИЧЕСКОЕ УПРАВЛЕНИЕ ДВИЖЕНИЕМ СУДНА В УСЛОВИЯХ ВНЕШНИХ ВОЗДЕЙСТВИЙ

Розглянуті питання підвищення якості та надійності автоматичного керування рухом судна в умовах зовнішніх впливів вітру і течії. Об'єктом дослідження є процес автоматичного керування рухом судна в умовах зовнішніх впливів вітру і течії. Предметом дослідження є метод і алгоритми підвищення якості та надійності автоматичного керування рухом судна в умовах зовнішніх впливів вітру і течії. Метою дослідження є розробка методу і алгоритмів підвищення якості та надійності автоматичного керування рухом судна в умовах зовнішніх впливів вітру і течії. Поставлена мета досягається за рахунок введення у схему керування рухом судна додаткового носового керма для отримання достатнього управління, формування, з використанням ПІД-регуляторів, сигналів керування бічним і кутовим рухами судна по відхиленню, швидкості відхилення та інтегралу відхилення виміряних значень бокового та кутового положення від програмних значень, розподілу сигналів керування між носовим і кормовим кермом таким чином, щоб забезпечувався рух судна без змішення відносно маршруту з нульовим кутом дрейфу. Це дозволяс, у порівнянні з традищійною схемою керування, зменшити лобовий опір руху судна, знизити витрати пального, поліпшити перехідні прочеси, зменшити кількість спраџювань виконавчих пристроїв, а також підвищити надійність за рахунок резервування (використання носового і кормового керма та подібних сигналів керування носовим $i$ кормовим кермом). Запропонований метод $i$ алгоритми перевірені математичним моделюванням у середовищі MATLAB прочесів автоматичного керування рухом судна в умовах зовнішніх впливів вітру $i$ течії. Експерименти підтвердили пращездатність запропонованого методу і алгоритмів, що дозволяє рекомендувати їх для практичного використання при розробиі математичного забезпечення бортового контролера систем автоматичного керування рухом судна.

Ключевые слова: объект управления, система управления, матерматическая модель, численное интергирование.

(C) Zinchenko S. M., Mamenko P. P., Grosheva O. O, Mateychuk V. M.

\author{
Статтю прийнято \\ до редакції 10.07.19
}

